\title{
Refractory Plasma Cell Neoplasm
}

National Cancer Institute

\section{Source}

National Cancer Institute. Refractory Plasma Cell Neoplasm. NCI Thesaurus. Code C7813.

A plasma cell neoplasm that is resistant to treatment. 